\title{
Macro nutrient status of Sundarbans forest soils in Southern region of Bangladesh
}

\author{
M. Z. Khan and M. S. Amin* \\ Soil, Water and Environment Discipline, Khulna University, Bangladesh
}

Received: 22 January 2018

Revised: 17 April 2018

Accepted: 23 May 2018

DOI: https://doi.org/10.3329/bjsir.v54i1.40732

\begin{abstract}
An attempt has been made to evaluate the condition of soil of the Sundarban mangrove forest of Bangladesh by applying standard method. Soil $\mathrm{pH}$ was varied from 6.63 to 7.87. Organic carbon of soil was found 4.06, 4.79, 5.59, 9.38 and $9.80\left(\mathrm{gKg}^{-1}\right)$ at Kotka, Kochikhali, Hironpoint, Harbaria, and Dublarchar, respectively. The electrical conductivity of soil was varied from 14.39, to 42.89 $\left(\mathrm{dSm}^{-1}\right)$ in the study areas. The cation exchange capacity in the soils was varied from 22.32 to 27.2 $\mathrm{Cmol}_{\mathrm{c}} \mathrm{kg}^{-1}$ in the study area. The average percentages of total nitrogen content in the soil were varied from 0.04 to $0.08 \%$. The soils of Oligohaline zone of Sundarban mangrove forest are rich in water soluble and exchangeable magnesium followed by calcium and the potassium. The percentages of silt and clay were higher than sand in all study areas. Dissolved chloride in the soil was found 7010, 4186,11750 and $16389\left(\mu \mathrm{g} \mathrm{g}^{-1}\right)$ at Hironpoint, Harbaria, Dublarchar and Kotka respectively.
\end{abstract}

Keywords: Sundarbans; Forest; Chemical attributes

\section{Introduction}

The Sundarbans is the largest, ecologically and biologically richest, and most extensive mangrove forest in the world. Ecosystems of this world heritage site supports versatile interactions and correlations and relationships among its vertebrates and invertebrates, flora, fauna, aquatic organisms, marine lives, wildlife, fishes, birds, natural habitats, micro soil and water relationship supports this largest wildlife habitats (Awal, 2007). Sundri (Heritierafomes) is the predominant tree species, supporting about $65 \%$ of the total merchantable timber (Chaffey et al., 1985; Pasha and Siddiqi, 2003). The Sundarbans forest is still the largest natural single tract of mangrove forest and habitats in the world (Hussain and Acharya, 1994) with 10, $029 \mathrm{~km}^{2}$ area. The total area of the part of Sundarbans in Bangladesh is now about $6,017 \mathrm{~km}^{2}$ (Chaffey et al., 1985), which arose due to the eastward shift of the Ganges (Naskar and Mandal, 1999).

The Sundarbans mangrove forests is the largest single block of the tidal halophytic mangrove forest of the world (Pasha and Siddiqui, 2003). Due to various anthropogenic activities, this forest is now under various stresses such as increased salinity and alteration in other physical and chemical composition in soil and water. Such changes in the soil properties are likely to affect the microbial communities in soil and hence the ecosystem properties including organic matter decomposition, nutrient mineralization and vegetation above the ground (Wardle, 2002). A mixture of these distinct soil types in various ratios forms loamy soil which usually has high humus content. Many soil properties are affected by soil texture, including drainage, water holding capacity, aeration, susceptibility to erosion, organic matter content, cation exchange capacity (CEC), $\mathrm{pH}$ buffering capacity and soil tilth (Berry, 2007).

The soils of Sundarbans are regularly flooded by diurnal tides. The knowledge of mangrove ecosystems is continually expanding. This knowledge is critical in order to ensure that effective mangrove management is maintained within the context of ecologically sustainable development. Though it is an important forest for its plants, animals and mangrove fishery but there is limited information regarding its soils. 
So, the present study has been undertaken to characterize the surface layer of Sundarbans forest soils in terms of macro nutrient status.

\section{Methods and materials}

The Bangladesh Sundarbans (between $21^{\circ} 13^{\prime} \mathrm{N}$ and $22^{\circ} 40^{\prime} \mathrm{N}$ latitude and $88^{\circ} 03^{\prime} \mathrm{E}$ and $89^{\circ} 55^{\prime} \mathrm{E}$ longitude) mangrove forest is bordered by Bangladesh in the east, the Hooghly River (a continuation of the River Ganga) in the west and the Bay of Bengal in the south. The temperature is moderate due to its proximity to the Bay of Bengal in the south. Average annual maximum temperature is around $35^{\circ} \mathrm{C}$. Average annual rainfall is $1920 \mathrm{~mm}$. Average humidity is about $82 \%$ and is more or less uniform throughout the year (Imam, 1982).

A total of five spots were selected (Fig. 1). From each of these spots, seven soil samples were collected; one from the centre of the spot, four (one each) from all the corners, and two from the middle sides of the spot. Therefore a total of 35 soil samples were taken. Soil samples were collected from $0-15 \mathrm{~cm}$ (surface) soil depth and all soil samples were kept in sealed plastic bags. Marking and labelling was performed with a detailed description of the selected sampling site on both the soil- plastic bags, and preserved in plastic bags until arrival at the laboratory for sample preparation and chemical analyses.

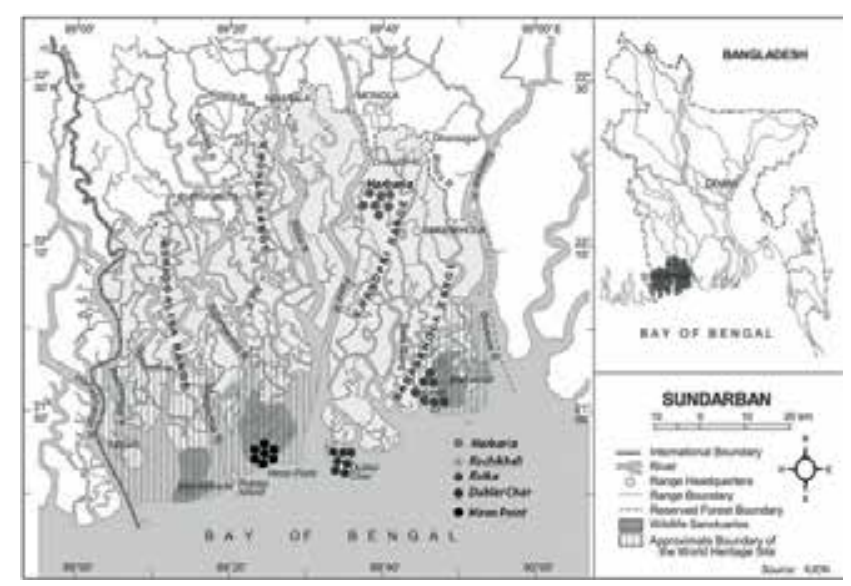

Fig. 1. Selected five soil sampling sites are showing the map(Gain and Das, 2014)

The collected soil was sieved through a 2 mmmesh screen to remove plant roots, rocks, and macro fauna. After sieving, soil samples were analyzed for physical, chemical and physicochemical properties. The particle size analysis of the soils was carried out by hydrometer method as described by Bouyoucos (1936) and Day (1965). Textural classes were determined using Marshall's Triangular Coordinate. Soil $\mathrm{pH}$ was determined electrochemically with the help of glass electrode $\mathrm{pH}$ meter maintaining the ratio of soil to water was 1: 2.5 as suggested by Jackson (1962). The electrical conductivity of the soil was measured at a soil: water ratio of 1: 5 by the help of EC meter (USDA, 2004). The CEC of the soils were determined by extracting the soil with $1 \mathrm{~N} \mathrm{KCl}(\mathrm{pH}$ 7.0) followed by the replacing the potassium in the exchange complex by $1 \mathrm{~N} \mathrm{NH}_{4} \mathrm{OAc}$. The displaced potassium was determined by a flame analyzer (Jackson, 1967). Total nitrogen of the soils was determined by colorimetric method (Bremner and Mulvaney, 1982) following $\mathrm{H}_{2} \mathrm{SO}_{4}$ acid digestion as suggested by Jackson (1967). Available phosphorus was extracted from the soil with $0.5 \mathrm{M} \mathrm{NaHCO}_{3}$ (Olsen Method) at $\mathrm{pH} 8.5$ and Molybdophosphoric blue colour method of analysis was employed for determination (Murphy and Riley, 1962). The available Na and $\mathrm{K}$ were determined from $\mathrm{NH}_{4} \mathrm{OAc}$. ( $\mathrm{pH}$ 7.0) extract as described by Jackson (1967). The extract was analyzed for available K and $\mathrm{Na}$ by a flame analyzer at 589 and $767 \mathrm{~nm}$, respectively (Jackson, 1967). Available sulphur content was determined by turbidimetric method as described by (Jackson, 1973). It was measured by spectrophotometer at $420 \mathrm{~nm}$. Organic carbon of samples was determined by Walkley and Black's wet oxidation method as outlined by Jackson (1962). The $\mathrm{Ca}^{2+}$ and $\mathrm{Mg}^{2+}$ of the soils were determined by extracting the soil with $1 \mathrm{~N} \mathrm{NH}_{4} \mathrm{OAc}$ (Soil: extractant $=1: 10$ ) followed by the replacing the $\mathrm{Ca}^{2+}$ and $\mathrm{Mg}^{2+}$ in the soil solution. Then the replacing the $\mathrm{Ca}^{2+}$ and $\mathrm{Mg}^{2+}$ was determined by titrimetric method (Lanyon and Heald, 1982). Chloride $\left(\mathrm{Cl}^{-}\right)$was extracted from the soil with distilled water and determined by Precipitation Titration method (Skoog et al., 1996). Data were processed and arranged by Microsoft Excel version, 2013 (Vermaat, 2014).

\section{Results and discussion}

The results of the study on assessment of physical and chemical properties of surface soils in sundarbans forest soils in Khulna district are presented and possible interpretations are made in this chapter. Some important physico-chemical and chemical properties are presented in Table I, II and III.

The percentage of sand, silt and clay and textural classes are presented in (Table 1). The highest clay (42.8\%) was found in soils of Hironpoint and lowest clay $(25.8 \%)$ was found in soils of Kochikhali area. Chaffey et al. (1985) found that Sundarbans soil is in general medium textured, sandy loam, silt loam or clay loam. Silt is the dominant grain in the sundarbans soil.

Table I. Percentage of sand, silt and clay was found in different study area of Sundarbans mangrove forest. 
Table I. Percentage of sand, silt and clay was found in different study area of Sundarbans mangrove forest

\begin{tabular}{lllll}
\hline Location & \%Sand & \%Silt & \%Clay & Textural class \\
\hline Harbaria & $9.3 \pm 0.06$ & $52.4 \pm 1.20$ & $38.3 \pm 1.65$ & Silty clay loam \\
Kochikhali & $22.8 \pm 0.09$ & $51.4 \pm 1.30$ & $25.8 \pm 0.98$ & Silt loam \\
Kotka & $20.3 \pm 0.08$ & $42.8 \pm 1.45$ & $36.9 \pm 1.21$ & Silty clay loam \\
Dublarchar & $10.2 \pm 0.07$ & $58.4 \pm 1.85$ & $31.4 \pm 1.30$ & Silty clay loam \\
Hironpoint & $10.3 \pm 0.09$ & $46.9 \pm 1.56$ & $42.8 \pm 1.85$ & Silty clay \\
\hline
\end{tabular}

The $\mathrm{pH}$ values in the soils was varied from $6.63 \pm 0.14$ to 7.83 \pm 0.04 in the study area (Table II). The highest $\mathrm{pH}$ (7.83) was found in soils of Kotka and lowest $\mathrm{pH}$ (6.63) was found in soils of Harbaria area. It is found that Harbaria area is neutral and the other four areas are mildly alkaline in the study area. Hassan and Razzaque (1981) found that the $\mathrm{pH}$ value of soil in Sundarbans is neutral to mildly alkaline under field conditions but in some localities the $\mathrm{pH}$ value of dried up sub soil samples drops to 6.5. Mahmood and Saikat (1995) reported the acidic $\mathrm{pH}$ values in the soil of Chakaria Sundarbans area and consequently, this area has a rich reserve of pyrite in its soil.

The electrical conductivity values in the soils were varied from $14.39 \pm 3.74 \mathrm{dSm}^{-1}$ to $42.89 \pm 9.38 \mathrm{dSm}^{-1}$ in the study area (Table II). The highest EC $\left(42.89 \mathrm{dSm}^{-1}\right)$ was found in soils of Kotka and lowest EC $\left(14.39 \mathrm{dSm}^{-1}\right)$ was found in soils of Harbaria area. It is found that Harbaria area is saline soil and the other four areas are highly saline soil.

The organic carbon content in the soils was varied from 4.06 $\pm 0.26 \mathrm{gkg}^{-1}$ to $9.80 \pm 0.35 \mathrm{gkg}^{-1}$ in the study area (Table 3). The highest organic carbon $\left(9.80 \mathrm{gkg}^{-1}\right)$ was found in soils of Dublarchar and lowest organic carbon $\left(4.06 \mathrm{gkg}^{-1}\right)$ was found in soils of Kotka area. Due to more decomposition of plant and animal residues in mangrove area the percentage of organic matter is higher than other soil tract. For this reason the biological activity in mangrove forest area is highly active. Zafar et al. (1999) stated that organic matter varied between $8.6 \mathrm{gkg}^{-1}$ and $19 \mathrm{gkg}^{-1}$ in the intertidal muddy beach of Bankhali river. Anderson (1977), Escourt (1967) and Mayer et al. (1985) reported that organic carbon is related to mud percentage in the soil. Mud percentage in the study areas were higher than sand and that is why organic matter was higher in the Sundarbans areas.
Total nitrogen content in the soils was varied from $0.04 \pm$ $0.003 \%$ to $0.08 \pm 0.011 \%$ in the study area (Table III). The highest nitrogen $(0.08 \%)$ was found in soils of Harbaria and lowest nitrogen $(0.04 \%)$ was found in soils of Kotka area.

This method of sulfur analysis measured mainly sulfate sulfur in soils. Available sulfur content in the soils was varied from $151.77 \pm 39.59 \mu \mathrm{g} \mathrm{g}^{-1}$ to $438.75 \pm 19.56 \mu \mathrm{g} \mathrm{g}^{-1}$ in the study area (Table III). The highest sulfur $(438.75 \mu \mathrm{g}$ $\left.\mathrm{g}^{-1}\right)$ was found in soils of Kotka and lowest sulfur (151.77 $\mu \mathrm{g} \mathrm{g}^{-1}$ ) was found in soils of Harbaria area. Sulfur concentration $>37.52 \mu \mathrm{g} \quad \mathrm{g}^{-1}$ indicated potential acid-sulfate soils in which oxidation of sulfides to sulfuric acid causes low pH (Soil Taxonomy Staff, 1994).

Available phosphorus content in the soils was varied from $53.16 \pm 1.81 \mu \mathrm{g} \mathrm{g}^{-1}$ to $62.56 \pm 8.97 \mu \mathrm{g} \mathrm{g}^{-1}$ in the study area (Table III). The highest phosphorus $\left(62.56 \mu \mathrm{g} \mathrm{g}^{-1}\right)$ was found in soils of Hironpoint and lowest phosphorus $\left(53.16 \mu \mathrm{g} \mathrm{g}^{-1}\right)$ was found in soils of Kochikhali area. Phosphorus is strongly bound in soils and tend to be a sink for added phosphorus. In acidic soils, phosphorus precipitates as iron and aluminum phosphates and it may be adsorbed onto iron and aluminum oxides (Boyd, 1995). In neutral and alkaline soils, phosphorus tends to precipitate as calcium phosphates.

Water Soluble and Exchangeable potassium content in the soils was varied from $166.39 \pm 48.30 \mu \mathrm{g} \mathrm{g}^{-1}$ to $644.40 \pm 55.61$ $\mu \mathrm{g} \mathrm{g}^{-1}$ in the study area (Table III). The highest potassium $\left(644.40 \mu \mathrm{g} \mathrm{g}^{-1}\right)$ was found in soils of Dublarchar and lowest potassium $\left(166.39 \mu \mathrm{g} \mathrm{g}^{-1}\right)$ was found in soils of Harbaria area. The availability of potassium depends on primary minerals, secondary clay minerals, organic matter, potassic fertilizer etc. present in the soil. Black (1965) demonstrated that the higher concentration of potassium in the surface layer in comparison to the subsurface layer might be due to the action of plant roots in transporting potassium to the surface and 


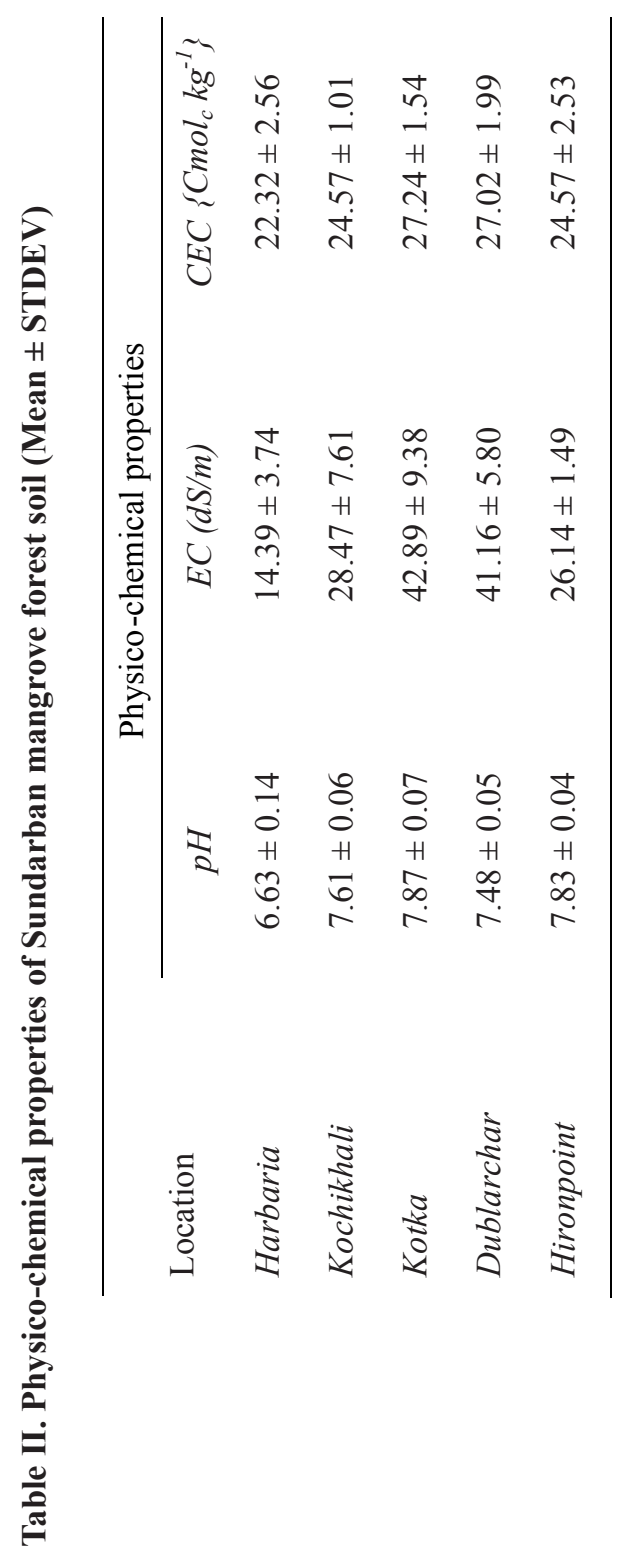

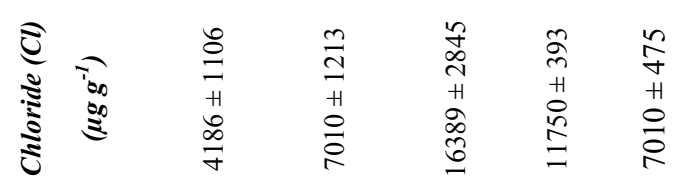

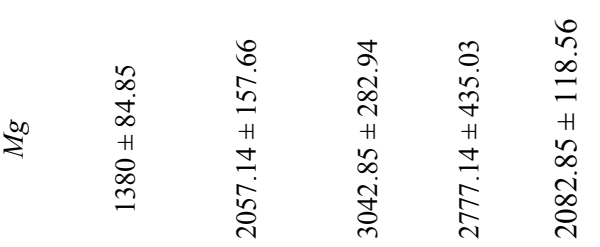

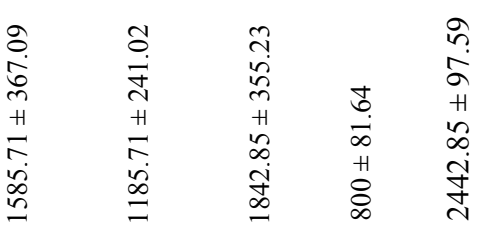

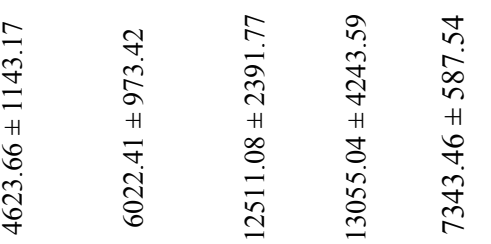

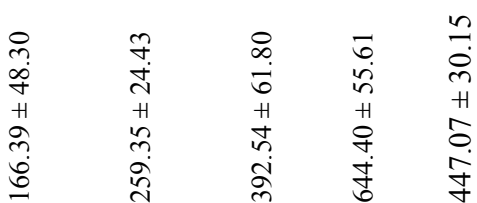

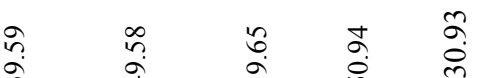

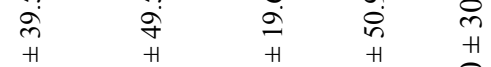

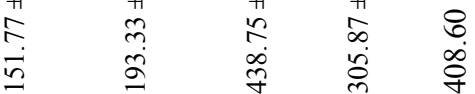

ڤ

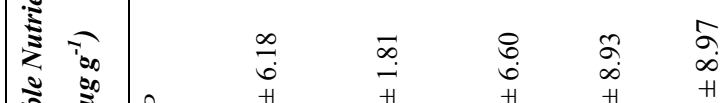

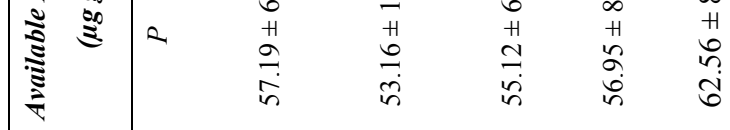

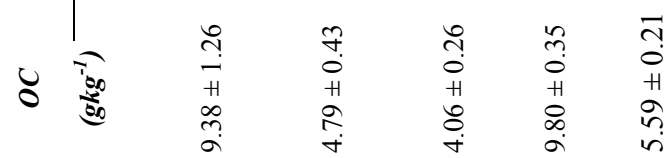

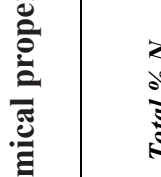

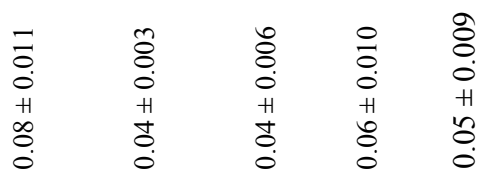

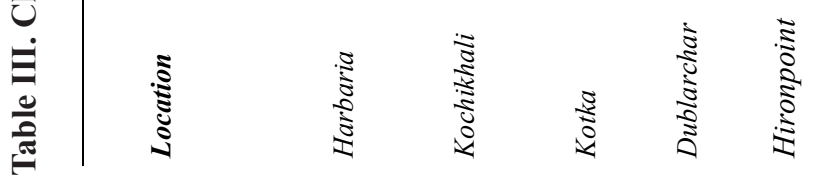


also addition of crop residues. He called it biological recycling of potassium in soils. Kemmler (1980) reported that the potassium availability was higher in submerged soils than in upland counter parts. Fine textured soils usually have a higher CEC and can hold more exchangeable potassium.

Water Soluble and Exchangeable sodium content in the soils was varied from $4623.66 \pm 1143.17 \mu \mathrm{g} \mathrm{g}^{-1}$ to $13055.04 \pm 4243.59 \mu \mathrm{g} \mathrm{g}^{-1}$ in the study area (Table III). The highest sodium (13055.04 $\left.\mu \mathrm{g} \mathrm{g}^{-1}\right)$ was found in soils of Dublarchar and lowest sodium (4623.66 $\left.\mu \mathrm{g} \mathrm{g}^{-1}\right)$ was found in soils of Harbaria area. Karim (1994) reported that the sodium $(\mathrm{Na})$ content is varied from 450 to 1850 $\mu \mathrm{g} \mathrm{g}^{-1}$ in the mangrove areas.

Water Soluble and Exchangeable calcium content in the soils was varied from $800 \pm 81.64 \mu \mathrm{g} \mathrm{g}^{-1}$ to $2442.85 \pm 97.59 \mu \mathrm{g} \mathrm{g}^{-1}$ in the study area (Table III). The highest calcium $(2442.85 \mu \mathrm{g}$ $\left.\mathrm{g}^{-1}\right)$ was found in soils of Hironpoint and lowest calcium (800 $\mu \mathrm{g} \mathrm{g}^{-1}$ ) was found in soils of Dublarchar area. Karim (1994) found the calcium (Ca) content was 2350 to $3950 \mu \mathrm{g} \mathrm{g}^{-1}$ in the Sundarbans.

Water Soluble and Exchangeable magnesium content in the soils was varied from $1380 \pm 84.85 \mu \mathrm{g} \mathrm{g} \mathrm{g}^{-1}$ to $3042.85 \pm$ $282.94 \mu \mathrm{g} \mathrm{g}^{-1}$ in the study area (Table III). The highest magnesium $\left(3042.85 \mu \mathrm{g} \mathrm{g}^{-1}\right)$ was found in soils of Kotka and lowest magnesium $\left(1380 \mu \mathrm{g} \mathrm{g}^{-1}\right)$ was found in soils of Harbaria area. Soils with a high CEC can adsorb greater amounts of major cations than soils with a low CEC and calcium and magnesium carbonates occurred in the samples.

Chloride content in the soils was varied from $4186 \pm 1106 \mu \mathrm{g}$ $\mathrm{g}^{-1}$ to $16389 \pm 2845 \mu \mathrm{g} \mathrm{g}^{-1}$ in the study area (Table III). The highest chloride $\left(16389 \mu \mathrm{g} \mathrm{g}^{-1}\right)$ was found in soils of Kotka and lowest chloride $\left(4186 \mu \mathrm{g} \mathrm{g}^{-1}\right)$ was found in soils of Harbaria area.

The cation exchange capacity in the soils was varied from $22.32 \pm 2.56 \mathrm{Cmol}_{\mathrm{c}} \mathrm{kg}^{-1}$ to $27.24 \pm 1.54 \mathrm{Cmol}_{\mathrm{c}} \mathrm{kg}^{-1}$ in the study area (Table II). The highest CEC (27.24 $\left.\mathrm{Cmol} \mathrm{kg}^{-1}\right)$ was found in soils of Kotka and lowest CEC (22.32 $\mathrm{Cmol}_{\mathrm{c}}$ $\mathrm{kg}^{-1}$ ) was found in soils of Harbaria area. Soil with a high CEC requires more liming material than soil of the same $\mathrm{pH}$ but of lower CEC. At the same degree of base unsaturation a soil with a higher $\mathrm{CEC}$ will provide greater concentration of cations such as $\mathrm{Ca}^{2+}, \mathrm{Mg}^{2+}, \mathrm{Na}^{+}$and $\mathrm{K}^{+}$in soil solution than a soil of lower CEC (Foth and Ellis, 1988).

\section{Conclusion}

Sundarbans soils are in general silt loam or silty clay loam. Silt is the dominant grain in the sundarbans soil. Soil reaction
$(\mathrm{pH})$ in Sundarbans is neutral to mildly alkaline under field conditions. Electrical conductivity in the study area was higher indicating higher dissolved chloride in soil. Clay percentage in the study area were higher than sand and that is why organic matter was higher in the Sundarban area. Total nitrogen is very low but available phosphorus and sulfur concentration are higher in the study area. In highly alkaline soil, phosphorus tends to precipitate as calcium phosphates. Fine-textured soils usually have a higher CEC and can hold more exchangeable potassium. The water soluble and exchangeable cations such as $\mathrm{Ca}^{2+}, \mathrm{Mg}^{2+}, \mathrm{Na}^{+}$and $\mathrm{K}^{+}$in soil solution are higher in the study area. The amount of macro nutrients varied due to the distance of saline water from different location of Sundarban forest soil.

\section{References}

Anderson SS (1977). The ecology of Morecambe Bay II, Intertidal invertebrates and factors affecting their distribution, J. Appl. Eco. 9: 161-178. doi.org/ 10.1007/BF02259190

Awal MA (2007), Analysis of possible environmental factors causing top-dying in mangrove forest trees in the Sundarbans in Bangladesh, $P h D$ thesis, University of Bradford. doi: 10.11648/j.bio.20140202.11

Berry (2007), Cornell University Agronomy Fact Sheet Series, Cornell University.

Black CA (1965), Methods of Soil Analysis. Part II. Ameri. Soci. Agro Inc., Madison, Wisconsin, USA.

Bouyoucos GJ (1936), Directions for Making Mechanical Analysis of Soils by the Hydrometer Method, J.Soil Sci, 42: 225-230. doi:10.1097/00010694193609000-00007

Boyd CE (1995), Bottom soils, sediment and pond aquaculture, Chapman and Hall, New York, USA.

Bremner JM and Mulvaney CS (1982), Nitrogen-total In: Methods of Soil Analysis, Part II. Eds. Page et al., $2^{\text {nd }}$ Ed., American Society of Agronomy, Madison, Wisconsin, USA 9: 595-624.

Chaffey DR, Miller FR and Sandom JH (1985), A forest inventory of the Sundarbans, Bangladesh; Main report. Project report, Ovearseas Development Administration, London, U.K 140: 195-196.

Day PR (1965), Particle Fractionation and Particle-Size Analysis In: Methods of Soil Analysis, Part I. Ed. Black CA, Soil Sci. Soci. America. 
Estcourt IN (1967), Distribution and associations of benthic invertebrates in a sheltered water soft bottom environment (Marlborough Sounds, New Zealand), New Zelend Journal of Marine Fisheries Research 1: 352-370. doi.org/10.1080/00288330. 1967.9515211

Foth HD and Ellis BG (1988), Soil fertility, John Wiley and Sons, Inc. New York, USA.

Gain D and Das SK (2014), Present status and decreasing causes of shellfish diversity of Passurriver, Sundarban, Bangladesh, AACL Bioflux 7(6): 483-488.

Hassan MM and Razzaque (1981), A Preliminary evolution of the clay mineralogy of the Sundarbans Soil, Bano Biggyan Patrika 10: 21-26.

Hussain Z and Acharya G (1994). Mangroves of the Sundarbans, Volume Two: Bangladesh, IUCN-The World Conservation Union, Dyna Print, Bangkok, Thailand.

Imam SA (1982), The Sundarbans and its future In: proceedings of the Second Bangladesh National Conference on Forestry, Dhaka, Bangladesh, pp 19-24.

Jackson ML (1962), Soil Chemical Analysis. Prentice Hall Inc., Englewood cliffs, New Jersey, USA.

Jackson ML (1967), Soil Chemical Analysis, Prentice Hall of India Pvt. Ltd., New Delhi, pp 498.

Jackson ML (1973), Soil Chemical Analysis, 2 ${ }^{\text {nd }}$ Ed., Prentice-Hall Inc, Englewood Cliffs, New Jersey, USA.

Karim A (1994), The physical Environment In: Mangrove of the Sundarbans, Eds. Hussain Z and Achanya G, Bangladesh IUCN, Bangkok 2: 11-42.

Kemmler G (1980), Priorities for alleviating soil related constraints to food production in the tropics, International Rice Research Institute,Los banos, laguna, philipines, pp 253-275.

Lanyon LE and Heald WR (1982), Magnesium, Calcium, Strontium and Barium In: Methods of Soil Analysis, Part II. Ed. Page et al., $2^{\text {nd }}$ Ed. American Society of Agronomy, Madison, Wisconsin, USA, 9: $252-255$.
Mahmood N and Saikat SQ (1995), On acid sulphate soils of the coastal aquaculture ponds of Bangladesh, Pakistan J. Mari.Sci. 4: 39-43.

Mayer LM, Rahim PT, Gwerin W, Macko SA, Walting L and Anderson FE (1985), Biological and granulometric controls on sedimentary organic matter of an interidal mud flat, Estua Coast Shelf Science 20: 491-503. doi.org/10.3923/jbs.2005.354.357

Murphy J and Riley JP (1962), A modified single solution method for the determination of phosphate in natural waters, Analytica Chimica Acta 27: 31-36. doi.org/10.1016/S0003-2670(00)88444-5

Naskar K and Mandal R (1999), Ecology and Biodiversity of Indian Mangroves, Publishing House, New Delhi, India, Volume, I \& II, pp. 21.

Pasha MK and Siddiqui NA (2003), Sunderbans, Banglapedia: National encyclopedia of Bangladesh, Asiatic Society of Bangladesh.

Skoog DA, West DM and Holler FJ (1996), Fundamentals of Analytical Chemistry, $7^{\text {th }}$ Ed., Thomson Learning Inc., USA.

Soil Taxonomy Staff (1994), Key to Soil Taxonomy, $6^{\text {th }}$ Ed., United States Department of Agriculture, Soil Survey Staff, Washington D.C., USA.

USDA (United States Department of Agricultur) (2004), Soil survey laboratory manual, soil survey investigation report no. 42, version 4.0, USDA-NRCS, Nebraska, USA.

Vermaat ME (2014), Introduction to Microsoft Office 2013, $1^{\text {st }}$ Ed., ISBN: 1285166027.

Wardle DA (2002), Communities and ecosystems: Linking the aboveground and belowground components, Princeton University Press.

Zafar M, Wouters K, Belaluzzaman AM and Islam I (1999), Occurrence, abundance and spawning of Lingulaanatina in the inter-tidal muddy beach of Bankhali river estuary, Bangladesh, Pakistan J. Mari. Bio. 5: 41-47. 